\title{
Credit Enhancement and Pricing in Financial Innovation- A Case Study of Asset Securitization
}

\author{
Rong $\mathrm{Fu}^{1,}$, Jingwen Yang ${ }^{2}$ \\ ${ }^{1}$ Department of Finance, Nanjing University of Science and Technology, Nanjing 210094, China \\ afurong_93@163.com
}

\begin{abstract}
Keywords: financial innovation; credit enhancement; pricing; asset securitization
Abstract. A new financial products is an important result of financial innovation, but in the market circulation it will encounter the problem of inadequate credit, in order to be accepted by the market it should go through credit enhancement.Based on this situation, this paper set asset securitization as an example.Its credit enhancement substance is analyzed and its pricing issues are discussed in order to further promote financial innovation.
\end{abstract}

\section{Introduction}

As one the most important financial innovation in the field of finance, the securities brought by asset securitization is one of the most dynamic financial products, which is able to bring cash flow support for the asset and realize the separation and recombination of the benefits and risks of assets.In today's financial markets, asset securitization is the most efficient way of financing after the deepen of market mechanisms. Therefore, the study of credit enhancement and pricing issues should also be strengthened in order to better promote financial innovation.

\section{Credit enhancement in financial innovation}

Financial innovation can take a variety of ways of credit enhancement to enhance the level of return on assets, and reduce financing costs.The so-called credit enhancement is based on the analysis of the risks of financial innovation, by taking a series of enhancement processed to realize the restructuring of the product risk and increase the external credit insurance, thereby improve the product reliability. Through credit enhancement, it also provides more protection for the rights and interests of investors.Currently, the credit enhancement adapted by the asset securitization mainly consists of two types: the seller credit enhancement and third-party enhancements.Among them, the seller credit enhancement is provided by the initiator. It includes the reservation of assets, purchasing or retaining the dependent claims and the risk of partition [1].The third-party enhancement is provided by a third party other than the main initiator. It includes corporate guarantees, cash collateral accounts, insurance and letters of credit. When companies issue bonds in order to achieve asset securitization, it often use a variety of measures of credit enhancement types combined.As shown in Table 1, the "Far East first phase of the leased asset benefit support plans" used the senior / subordinated structure and Sinochem guarantee these two types of credit enhancement mode. 
Table 1 The credit enhancement of asset securitization of a few enterprises

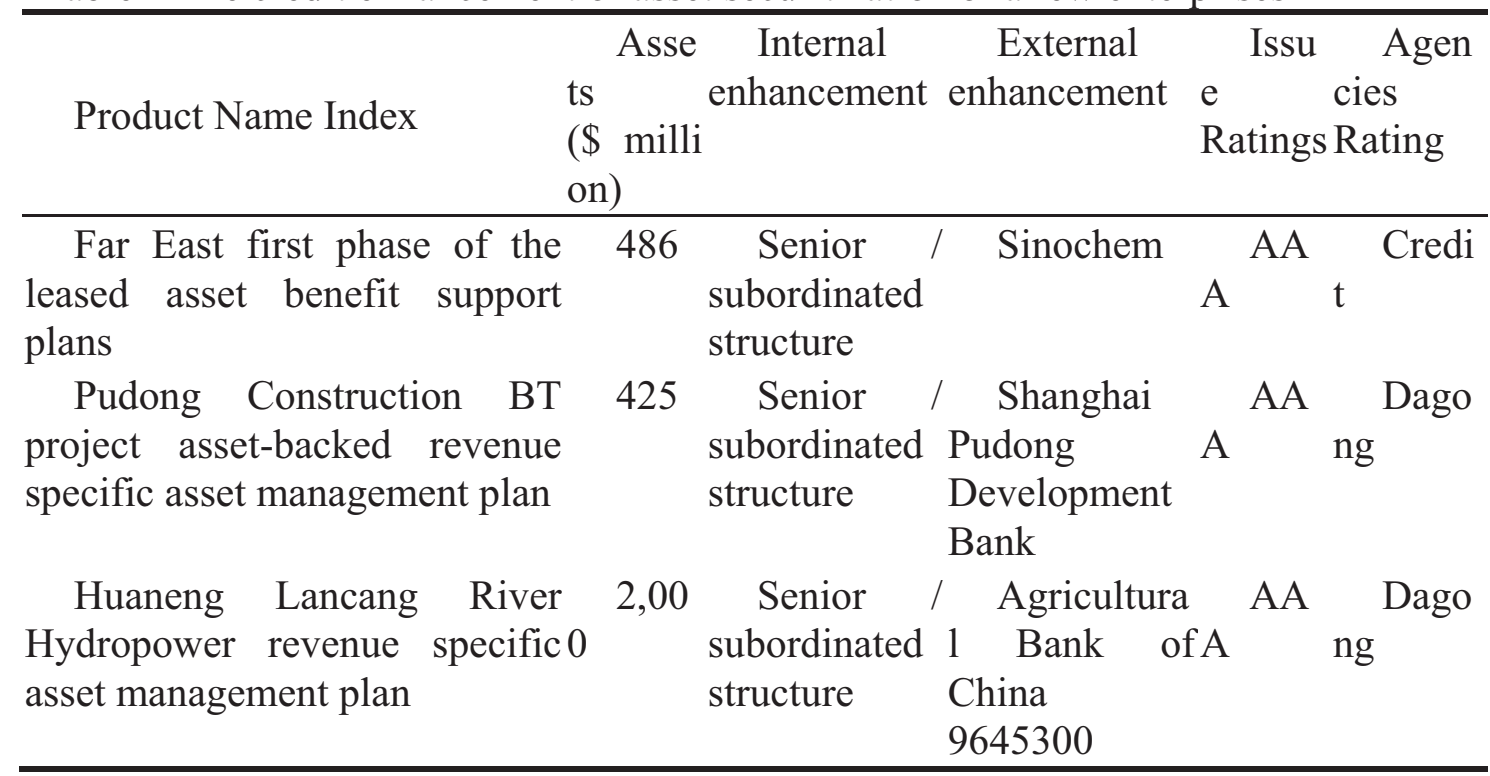

Unlike enterprise asset securitization, credit asset securitization usually take internal credit enhancement methods, namely, the main achievement of credit enhancement by banks credit business [2].As shown in Table 2, take that way only through internal arrangements securities it will be able to achieve the desired credit rating to meet the needs of investors.

Table 2 A few credit enhancement of asset securitization

\begin{tabular}{|c|c|c|c|c|}
\hline Product Name Index & $\begin{array}{r}\text { Assets } \\
(\$ \text { million } \\
\end{array}$ & $\begin{array}{c}\text { Internal } \\
\text { enhancement }\end{array}$ & & $\begin{array}{l}\text { External } \\
\text { hancement }\end{array}$ \\
\hline $\begin{array}{l}\text { Jianyuan } 2007-1 \text { personal housing } \\
\text { mortgage-backed securities }\end{array}$ & 4,161 & \begin{tabular}{l}
\multicolumn{1}{c}{ Senior } \\
subordinated \\
structure
\end{tabular} & / & None \\
\hline $\begin{array}{l}\text { 2008-1 Kaiyuan credit asset-backed } \\
\text { securities }\end{array}$ & 3,766 & $\begin{array}{l}\text { Senior } \\
\text { subordinated } \\
\text { structure } \\
\text { Excess spread } \\
\text { Liquidity } \\
\text { reserves }\end{array}$ & / & None \\
\hline $\begin{array}{l}\text { Jianyuan 2008-1 reforming asset } \\
\text { securitization trust }\end{array}$ & 2,765 & \begin{tabular}{l}
\multicolumn{1}{c}{ Senior } \\
subordinated \\
structure
\end{tabular} & 7 & None \\
\hline
\end{tabular}

In particular when taking enhancement mode or a combination of enhancement mode, features and assets should be combined with feature selection for their environment, the ultimate goal is to achieve the stated objectives in utility bonds issuance cost constraints being maximized (as shown below 1), or to achieve the stated objectives in a cost effectiveness being minimized.

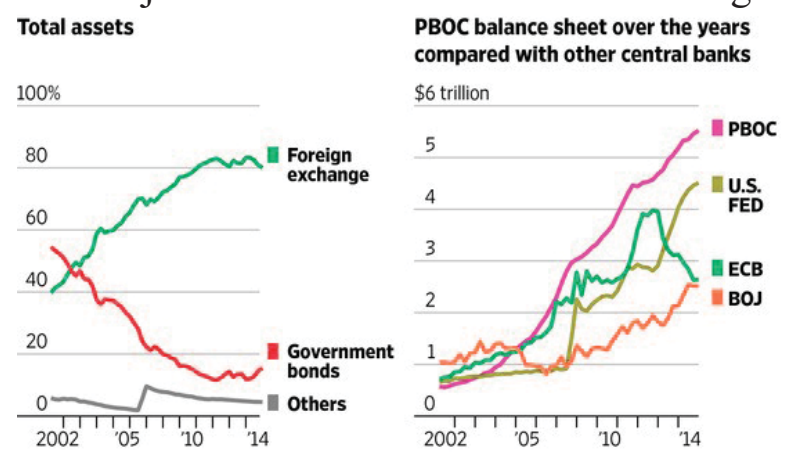

Figure. 1 Maximized Utility Bonds Issuance Cost Constraints 


\section{Pricing in Financial Innovation}

To achieve the credit enhancement of asset securitization, it must make sure that the parties in the credit enhancement can achieve the balance of interests, so that the provider of the credit enhancement would be willing to supply credit. To achieve the balance of interests, it needs to analyze the asset value change of various economic agents brought before and after the enhancements.As shown in Table 3, before the asset credit enhancement, credit providers have high credit tangible assets $\mathrm{W}$ intangible assets $\mathrm{W}$ and intangible assets 1 , of which the latter is subject to credit or reputation. The party who needs the enhancement owns weak assets W.In taking the credit enhancements, if the credit risk does not occur, the value of assets owned by credit providers will increase, that is tangible $\mathrm{W}+$ tangible $1 \mathrm{~W}+$ enhancement $\mathrm{W}$, the assets of those who needs credit enhancement will become weak $\mathrm{W}+$ tangible $2 \mathrm{~W}$ - increased value $\mathrm{W} 2=$ strong $\mathrm{W}$.

Table 3 Various economic changes in the value of assets when credit risk has not occurred

The value of assets before Credit providers Credit demander
and after enhancement

\begin{tabular}{ccc} 
Before enhancement & tangible $\mathrm{W}+$ intangible 1 & W Weak \\
After enhancement & $\mathrm{W}$ & \\
& $\mathrm{W}+$ Tangible $\mathrm{W}+$ intangible 1 & Weak $\mathrm{W}+$ intangible 2 \\
& $\mathrm{W}$ - increased value $\mathrm{W}$ \\
\hline
\end{tabular}

In the process of credit enhancement, interest rate risk, liquidity risk and other risks may also occur.As shown in Table 4, when the value of assets credit providers be weakened, those who need the change did not occur, because the paid $\mathrm{W}$ and intangible $2 \mathrm{~W} 2$ is actually equal.

Table 4 Various economic changes in the value of assets when a credit risk occurs

The value of assets before Credit providers Credit demander and after enhancement

\begin{tabular}{lcc} 
Before enhancement & tangible W + intangible 1 W & Weak W \\
After enhancement & Tangible W 1 + intangible W & weak W + paid W \\
+ increased value W - paid W & paid - increased values \\
& & W \\
\hline
\end{tabular}

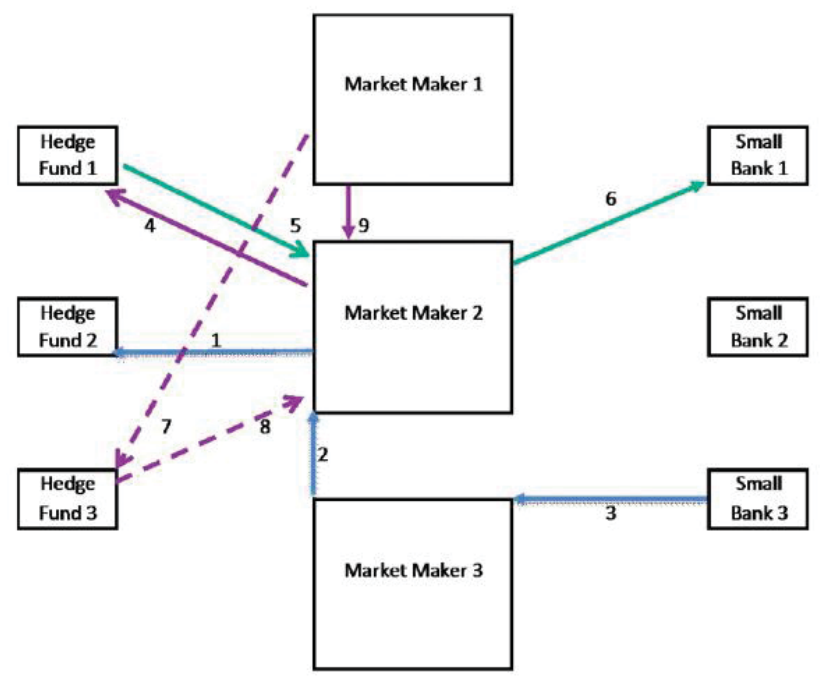

Figure. 2 Process of Credit Enhancement

In the process of credit enhancement, risk and intangible assets are difficult to change, only the increased value $\mathrm{W}$ by the enhancement can be artificially controlled.The fact that whether it can achieve the maximum change of expected asset value of the credit demanders directly related to the achievability of the credit enhancement. To solve it with the utility function, you can maximize the optimal enhancement rates [3].If the value is less than the value of the rate it can not achieve 
maximum efficiency, when greater than this value it needs to pay cost at an overly high level, thereby the best enhancement fee rate should be set as the maximized optimal enhancement rate.

\section{Conclusion}

Through the analysis we can find that, it requires credit enhancement to let the asset securitization be gradually accepted by the market.In this process, it also needs to achieve a reasonable price in order to make the various stakeholders involved in credit enhancement to maintain the balance of interests. Thus, in the process of financial innovation, the research on the credit enhancement and pricing should be strengthened in order to better promote new financial products.

\section{References}

[1] Hollander H, Prokop J. Stock price effects of asset securitization: The case of liquidity facility providers[J]. Quarterly Review of Economics \& Finance, 2014, 57:147-160.

Reference to a book:

[2] Alafita T, Pearce J M. Securitization of residential solar photovoltaic assets: Costs, risks and uncertainty[J]. Energy Policy, 2014, 67(2):488-498.

[3] Lützenkirchen K, Rösch D, Scheule H. Asset portfolio securitizations and cyclicality of regulatory capital[J]. European Journal of Operational Research, 2014, 237(1):289 - 302. 